\title{
De/Motivations in Housing Microfinance Delivery in Ghana
}

\author{
${ }^{1}$ Bondinuba, F. K., ${ }^{2}$ Hedidor, D., ${ }^{3}$ Opoku, A., ${ }^{4}$ Teye A. L \\ ${ }^{1}$ Institute for Social Policy, Housing, Environment and Real Estate \\ School of Energy, Geoscience, Infrastructure and Society, Heriot-Watt University-UK \\ ${ }^{2}$ Oboadaka Local Authority Junior High School, Akwapim South District, Ghana \\ ${ }^{3}$ UCL Bartlett School of Construction and Project Management, University College London, 1-19 Torrington Place, \\ London WC1E 7HB \\ ${ }^{4}$ Delft University of Technology, Faculty of Architecture and Built Environment, P.O Box 5043, 2600 GA, Delft, \\ The Netherlands
}

\begin{abstract}
Purpose - The purpose of this paper is to explore the de/motivation variables in the delivery of housing microfinance (HMF) in the low-income housing market in Ghana.

Design/methodology/approach - The paper relied on a survey of 125 respondents of microfinance institutions (MFIs) to understand the interactions and effects of these variables on HMF delivery in Ghana. Descriptive and bivariate statistical methods were used to analyse the data.

Findings - The findings revealed that both internal and external variables motivate MFIs to engage in the lowincome housing market. These variables are: MFIs desire for expansion, the potential size of the low-income housing market, the market potential for MFIs growth, the availability of local resources, unique features and products of the market, low-income housing offering an opportunity for leveraging resources and the preference for homeownership than rental among individuals in the low-income segment of the population. However, variables such as capital lockup in HMF delivery, high-interest rates in the country, high cost and land prices, high cost and price of building materials, lack of sufficient collaterals and the different interest rates required on HMF loans also served as demotivation in the low-income housing market in Ghana.
\end{abstract}

Research limitations/implications - The paper findings are limited in context to Ghana.

Practical implications - The paper, although limited to Ghana, contributes to the much-needed body of knowledge on low-income housing finance in developing countries.

Originality/value - The paper is the first of its kind in using empirical data to explore the motivational and demotivational variables in the delivery of HMF in a developing country context such as Ghana.

Keywords: Motivation, Microfinance, Ghana, Housing, Developing countries, Low-income groups

Paper type Research paper 


\section{Introduction}

The growth of the housing market in developing countries has in recent times been of great concern and interest to many stakeholders including researchers. The interest in the growth of the housing market is because of its economic contribution to the overall Gross Domestic Product and economic growth in these emerging markets (Stiglitz, 1993; Calvo et al., 1996). As such, the provision of low-income housing is no longer considered as a social obligation by the state, but as a means of economic growth and poverty reduction (cf. Jack and Braimah, 2004; Nima, 2004). Furthermore, the importance of low-income housing market in contributing to job creation and the overall output growth of a country economy is also widely accepted in both developed and emerging markets (cf. Keivani and Werna, 2001; Buckley and Kalarickal, 2005). The process of transformation and expansion of such an important sector of the economy from the individual low-income groups to the national and global perspectives is also attracting much interest within and outside the housing market.

Moreover, the development of low-income housing market in developing economies is also seen as an avenue to accelerate the achievement of wider economic and socioeconomic objectives that includes poverty reduction by many stakeholders (Krieger and Higgins 2002; Bondinuba, 2016). The provision of jobs and the use of housing and its related activities for business growth and family unionisations is another benefit of the housing market in developing countries (Sengupta, 2013; Lerbs, 2014). Furthermore, the housing market in many emerging markets such as Ghana, although not well structured, operates on two levels: formal and informal market segments (cf. Keivani and Werna, 2001; Arku et al., 2012). The informal housing market constitutes the largest, and its products are mostly low-income housing provided through the support of families, friends and to a large extent by the individual home builder. Low-income housing is arguably a nonspecific expression used to refer to the type of housing that is within the means of low-income earners, usually in developing countries. Low-income housing assumes the characteristics of supply side oriented financing by a combination of public and private funding which targets the low-income groups of the society (Bondinuba et al., 2013). Many professionals, artisans and labourers are informally employed in this sector. The informal housing market can, therefore, be considered as having the potential of providing a large percentage of both manufacturing and service employment particularly in Ghana. Despite the importance and benefits of this sector, 
many poverty-stricken households and individuals who constitute the larger proportion of this market are unable to access finance on a sustainable basis to meet their housing needs. Such segment, therefore, becomes the largest underserved regarding access to housing finance in the entire housing market in Ghana.

Growth-oriented MFIs, having realised the potential of such an important but untapped market, has started making the most tangible contribution towards economic growth and job creation in the private sector of these economies where they operate. They do so through the provision of competitive and innovative products such as HMF in two ways. The first tangible contribution is that they act as leading agents or subcontractors of both multilateral and bilateral donor funding organisations or their respective local governments (Bondinuba, 2016). Secondly, they also act as venture firms in their own rights (Quaye et al., 2014). A large number of MFIs have emerged in recent times in many emerging economies including Ghana, to serve the unsatisfied demand for financial services-particularly to meet various needs of the low-income groups which include housing. These institutions usually focus on providing other services to individuals and small businesses in either one or the combinations of credit provision and deposit collection (Basu et al., 2004).

However, the Ghanaian housing literature has been skewed towards mainstream mortgage financing with less focus on the advancements of low-income housing finance such as HMF delivery (cf. Tipple et al., 1999; Arku et al., 2012; Obeng-Odoom, 2013; Nimako and Bondinuba, 2013; Yankson and Gough, 2014; Afrane et al., 2014). These studies are mostly in the context of housing policies, rental issues and the demand and supply of housing in Ghana. Little is known about the variables that serve as motivations to MFIs that engage in the low-income housing market and vice versa. The above indicates a general lack of knowledge regarding the broader implications of these variables for the low-income groups and the institutions engaging in such markets. Furthermore, since the publication of most of the above studies, the scope of the Ghanaian housing market has changed significantly, especially regarding housing demand and supply. The purpose of this paper, therefore, is to identify and evaluate the variables that motivate entry and non-entry of MFIs into the low-income segment of the housing market in Ghana. It adopted a quantitative research strategy with a survey of 125 respondent MFIs in Ghana. The 
paper is structured into five sections with Section 2 dwelling on the concept of HMF in the lowincome housing market. Section 3 describes the research approach and data analyses, while Section 4 contains the discussion of the findings and their implications. Section 5 concludes the paper and recommends potential areas for future research.

\subsection{The Concept of Housing Microfinance in the Low-income Housing Market}

The concept of HMF emerged from microfinance as an innovative financing strategy with its high potential hitherto untapped. As such, MFIs which provide HMF continues to strive toward providing accessible and affordable finance on a sustainable basis to low-income groups of the population in emerging markets (Pedrini et al., 2016; Bondinuba, 2016). This effort by MFIs particularly is to enable low-income earners in developing countries to meet their housing needs (Bondinuba et al., 2016). This is because HMF works on the principles and concepts of how most individual low-income groups are housed through the incremental building process. To better understand HMF delivery, Daphnis and Ferguson (2004) described it as the intersection between housing finance and microfinance. Ritchie (2011) also suggested that it is the combination of pro-poor real estate development using microfinance principles with emphasis on housing support services and community development. In this regard, (Bondinuba, 2016) also noted that HMF refers to the application and use of microfinance services, strategies and products to meet the housing needs of individual low-income groups as well as attempting to address the housing value chain constraints of low-income housing based on the concepts of microfinance approaches. This paper adopts the definition of Bondinuba, (2016) for this study.

The concept in its entirety is a new and an innovative strategy in many emerging markets' housing finance sectors which operate on a 2- way approach (Malhotra, 2002; Daphnis and Ferguson, 2004). Individual low-income groups can either access cash loans for home improvement, or they can get skills on how to build their housing and through loaned construction materials (Littlefield et al., 2003; Kono and Takahashi, 2010). Furthermore, HMF is a more appropriate lending method and strategy for serving the housing finance needs of individual low-income groups than traditional mortgage lending (Schumman, 2004; Cain, 2007). This is because HMF guarantees flexibility of access and repayment terms. There is flexibility due to the small nature of the amount that is usually given out for the incremental building 
process of individual low-income groups. Collateralisation issues until recently have also not been much of a problem in HMF design and delivery (Derban et al., 2002). HMF programs also have the potential of being integrated into any MFI's existing micro enterprise operations without any adverse effect on the quality or growth of the existing portfolio (Daphnis and Ferguson, 2004). Furthermore, it would be very easy for any MFI's existing loan or credit officer to be trained to offer HMF loans without any difficulties or negatively affecting their productivity (Ferguson and Smets, 2010). MFIs which adopt, design and develop HMF for the low-income housing market would be contributing to the innovation and entrepreneurship efforts in both housing and microfinance industries.

However, in the case of developing countries and from individual low-income group's perspectives, the success of delivering HMF borders on affordability issues. Affordability is affected by individuals' income status which compels them to build incrementally over a long period. Evidence suggests that about 33\% of Ghanaians resort to alternative arrangements such as living with relatives, living in informal housing on undeveloped land or living in tents, kiosks, containers or shops due to the shortage and lack of affordable housing in the country (CAHF, 2015; Bondinuba, 2016). CAHF (2015) estimates that about $96.6 \%$ of the Ghanaian population rely on affordable housing finance mechanisms to attain home ownership. Moreover, the Ministry of Water, Resources, Works and Housing, reported in 2013 that the country's housing deficit was around 1.7 million units. The most widely affected by the housing deficit is the lowincome segment of the population. Likewise, both rural and urban average household incomes are insufficient to purchase the cheapest newly built house, constructed by formal developers (Sarfoh, 2010; CAHF, 2015). Only 3.4 percent of the population could practically purchase houses built by a formal developer. The Ghanaian housing market thus favours self-built solutions. Kwofie et al. (2011) also indicate that as much as $90 \%$ of housing in Ghana is selfbuilt. This is commonly financed through accumulated savings, home loans from nongovernmental organisations (NGOs), microfinance institutions and support from relatives (Awuvafoge, 2013; Bondinuba et al., 2014).

The above phenomena are as results of low income, higher cost of land, among others, which raise affordability issues (Karley, 2008). The Ghana National Shelter Policy, (2015), defines affordability as being relative to household gross annual income. Affordability regarding housing 
consumption requires a household to spend no more than 30 percent of its gross annual income from the rental or purchase of housing (Karley, 2008; Boamah, 2010). However, in the case of Ghana, the lower social, economic segment of the population spend more than $30 \%$ of the annual gross income on housing and its related cost (Boamah, 2010).

\subsection{The Role of Microfinance Institutions in Housing Microfinance Delivery}

One basic feature of most HMF schemes is that they involve the collaboration among the public, private and other third-party institutions and organisations. HMF delivery involves risk sharing relationship in joint decision-making, financial and technical resource commitment as well as benefits from the comparative and interdependence among the parties and stakeholders. Prior studies indicate that the design and application of HMF consist of networks of heterogeneous inter-dependent actors (cf. Ferguson and Navarrete, 2003; Chakrabarti, 2004; Daphnis and Ferguson, 2004). These actors evolve around governance and socio-economic development perspectives through the principle of savings and loans to alleviate poverty among the urban and rural poor. The collaborations and partnerships consist of values, processes and institutions which aim at addressing the complex social issues such as poverty and other human livelihood challenges. Institutions in this context relate to the system of interactions and interdependent organisations usually put together by the state or private sector actors or investors for collaborations within established norms, rules and constitutions (Klijn and Koppenjan, 2000; Kumar, 2004). These institutions, in the case of MFIs, play a significant role in the progress, development and stability of society (Coase, 1998). In low-income housing provisions, (UNCHS, 1996; Habitat, 2006), identified institutions as vital components in the formulation, implementation and monitoring of housing policies and programmes while ensuring community and societal development. Madu and Umebali (1993) also demonstrated the role of indigenous institutions in capital and community resource mobilisation in emerging economies. The role and consequences of the interactions among institutions such as MFIs generate diverse settings which may be linked to the formation, composition and socioeconomic characteristics of themselves (Akinola, 2007; Srnec et al., 2013). Hence, Klijn and Teisman (2002) suggest that the structure and socioeconomic characteristics of an institution and the contextual situations in which they operate determine the outcomes of their interactions within a system such as the low-income housing value chain. 
However, many use the term microfinance institution and 'micro credit institution' interchangeably. Ahmed et al. (2013. p 211) therefore proposed that for an MFI to qualify and be accorded as such it must be considered to be "social enterprise whose primary mission is to improve the lives of poor people through the provision of financial services”. They argued that any profit-seeking institution could also be classified as such so far as it does satisfy the above criteria. Such institutions must adhere and adopt the philosophy of 'double bottom line’ approach, which is more focus on improving the lives of the low-income groups of the population. Social enterprise according to (Yunus, 2007) is a non-loss, non-dividend enterprise, created with the intention to do good to people, to bring positive change to the world, without any short-term expectation of making money. In this context, HMF loans are supposed to be carried out without collateral, and the lender has no legal recourse to recover a loan if the borrower is unable to repay. The above definitions may remove the MFI label from many legitimate institutions operating as MFIs in developing countries including Ghana. It may also affect those offering collateralized loans to small and medium enterprises and low-income earners. Most profitseeking MFIs, whose main objective is to be loyal to their shareholders, may not also, be considered as MFIs unless their work aimed at benefitting the poor.

Notwithstanding the above, MFIs whether they operate as profit or non-profit seeking institutions would be motivated to be efficient and manage their HMF portfolios based on certain motivations. These motivations could be positive or negative forces which exist in the lowincome housing market. An understanding of these forces is helpful for MFIs to be conversant with the motivations of individual low-income groups in patronising their products within the context of the role they perform in the housing value chain. However, Bondinuba et al. (2014) suggested that motivating individual low-income groups as clients would be one of the most complex concepts for MFIs particularly in developing countries such as Ghana. This is because of the complexities and non-permanency of most urban individual low-income groups who migrate internally within the urban centres. Furthermore, understanding the motivation would steer MFIs to innovate and become more productive, therefore ensuring organisational survival (Bondinuba, 2015). Understanding the de/motivation variables would help MFIs to aim at scaling up profitably. It can also contribute to sustaining the organisation and HMF portfolio as well as the housing market. Moreover, MFIs would better enhance their organisational or corporate 
image and ensure better inter-industrial relations with microfinance and housing markets (Bondinuba, 2016). More importantly, motivation would drive MFIs to be acceptable to change and ensure a better-quality orientation and better productivity in the delivery of HMF to individual low-income groups. It is on the above premise that this paper sought to discover the variables within the low-income housing market that serve as de/motivation to MFIs which may consider delivering HMF to individual low-income groups in Ghana.

\subsection{Research Approach and Data Analysis}

The study used quantitative data from questionnaire research techniques to achieve the research aim. The study adopted a broader view of the de/motivational variables for MFIs entry and nonentry into the low-income housing market in Ghana. The motivation for using questionnaire was to be able to reach a target group in a more practical and efficient way. A predetermined question response options were used among a cross-section of non-HMF providing institutions. This was to eliminate any possible bias associated with interviews and to obtain a wider view of respondents from the Ghanaian microfinance industry. The study used thirteen, and twelve of the demotivation and motivation variables developed from both extant literature and interviews with three housing microfinance institution in Ghana (cf. Panayotou, 2002; Smets, 2006; Cain, 2007; BOG, 2007; Yunus, 2007; Daphnis and Ferguson, 2004; Metzel, 2009; Ritchie, 2011; Littlefield et al., 2003; Kono and Takahashi, 2010; Schumman, 2004; Cain, 2007; Ferguson and Navarrete, 2003; Chakrabarti, 2004; Daphnis and Ferguson, 2004; Bondinuba et al., 2014; Bondinuba, 2015). Part one of the questionnaires sought the general information about respondents and their organisations. Part two asked respondents to state their level of agreement with the 25 variables as possible demotivation and motivations associated with the delivery of HMF using a five-point Likert scale of 1 - strongly disagree to 5 - strongly agree.

\subsection{The Data Collection Process}

The questionnaires were administered to MFIs in the Greater Accra and Ashanti regions. In total, 200 questionnaires were distributed to MFIs: 120 and 80 in Greater Accra and Ashanti regions respectively. This was because many MFIs operating in the country are in these regions. Furthermore, it was also due to their strategic importance regarding their socio-economic activities, population and volume of construction activities. The survey was conducted between 
August 2014 and December 2014 as part of a postgraduate research study. Snowball sampling was used to identify respondent institutions from the population because a "standard" sampling approach was difficult and uneconomical. Using this method, easy to reach MFIs were approached to participate. The results yielded a sample of 200 MFIs from which 135 completed questionnaires were received as shown in Table 1 . The summary of the survey data indicates that a response rate of $68 \%$ was achieved. However, $7 \%$ of the responses were unusable due to errors, inconsistencies and incompleteness. The above results could be considered as good since prior studies suggest that variations in the nonresponse rates do not necessarily change or affect surveys (Keeter et al., 2000; Merkle and Edelman, 2002). The important thing to do as a researcher is to minimise the nonresponse rates. Babbie (2007, p. 262) is also emphatic in his view about response rate of survey research. He argues that extant literature on social science indicates that "a response rate of at least 50 percent is considered adequate, 60 percent is good [and] 70 percent is very good" for analysing and reporting context. To increase the response rate, respondents were contacted by telephone to obtain their office locations and directions before sending the surveys out. Follow-up reminders through phone calls almost every week also facilitated the response rate that was recorded.

Table 1. Questionnaire distribution within the regions

\begin{tabular}{|l|c|c|c|c|c|c|}
\hline $\begin{array}{l}\text { Distribution } \\
\text { within regions }\end{array}$ & $\begin{array}{c}\text { Number } \\
\text { distributed }\end{array}$ & $\begin{array}{c}\text { Percentage } \\
\text { (\%) }\end{array}$ & Nr Collected & $\begin{array}{c}\text { Percentage } \\
\text { (\%) }\end{array}$ & $\begin{array}{c}\text { Nr found suitable } \\
\text { for analysis }\end{array}$ & Percentage (\%) \\
\hline Greater Accra & 120 & 60.0 & 80 & 59.3 & 74 & 59.2 \\
Ashanti & 80 & 40.0 & 55 & 40.7 & 51 & 40.8 \\
\hline Total & 200 & 100.0 & 135 & 100.0 & 125 & 100.0 \\
\hline
\end{tabular}

\subsection{Preliminary Analysis}

Data collected were analysed using descriptive statistics with the help of the statistical package for social sciences (SPSS) version 22 software. The 25 de/motivator variables were analysed using mean, standard deviation and ranking strategy to extract the critical variables among them. Furthermore, agreement on the rankings of the variables was tested using the Mann-Whitney Utest. Reliability is the extent to which data collection and analytical techniques yield consistent findings. To demonstrate the reliability of the questionnaire survey, the Cronbach's coefficient was used to examine the internal consistency of the scale (Easterby-Smith et al., 2008). A Cronbach's $\alpha$ value greater than 0.70 is widely considered as sufficient (Pallant, 2010). Both standardised and non-standardised Cronbach's $\alpha$ computed gave the same value of 0.82 as shown 
in Table 2 below. It means all the variables are reliable. The content validity of the questionnaire was based on the literature review and interviews as stated above as well as the subjective opinions of two HMF experts. Therefore, the content validity of the questionnaire was also achieved.

Table 2. The Cronbach's $\alpha$ Value

\begin{tabular}{|c|c|c|c|c|c|}
\hline \multicolumn{4}{|c|}{ Scale Statistics } & \multicolumn{2}{c|}{ Reliability Statistics } \\
\hline $\begin{array}{c}\text { Nr of } \\
\text { Variables }\end{array}$ & Mean & Variance & S. D & $\begin{array}{c}\text { Cronbach's } \\
\text { Alpha }\end{array}$ & $\begin{array}{c}\text { Cronbach's Alpha Based on Standardized } \\
\text { Items }\end{array}$ \\
\hline 25 & 137.66 & 177.02 & 13.31 & 0.82 & 0.82 \\
\hline
\end{tabular}

\subsection{General Characteristics of Respondents’ Institutions}

A breakdown of the respondents who participated in the survey shows that out of the 125 respondents who returned the valid questionnaires, 59\% of them are in the Greater Accra region while $41 \%$ are in the Ashanti region as shown in Table 1. Respondents from Greater Accra region were $(19 \%, n=25)$ higher than those in the Ashanti region. Although Ashanti region is noted for its variety of businesses, the Greater Accra region currently has the largest share of the Ghanaian population with about 4.0 million (GSS 2013). Regarding respondent institutions knowledge concerning HMF delivery, 18\% had a sound understanding but were however not engaged in HMF delivery for various reasons. Among these reasons includes high risks in term of capital locked-up and the high financial capital outlays required to undertake such a venture.

Table 3. Respondents’ firms’ knowledge of housing microfinance

\begin{tabular}{|l|c|c|c|c|}
\hline Valid & Frequency & Percent & Valid Percent & Cumulative Percent \\
\hline Yes & 22 & 17.6 & 17.6 & 17.6 \\
No & 103 & 82.4 & 82.4 & 100.0 \\
\hline Total & 125 & 100.0 & 100.0 & \\
\hline
\end{tabular}

Regarding firm characteristics, four variables characterised the chosen firms surveyed as shown in Table 4 below. These variables were the firms' years of operation, the source of finance, annual income and target clients. Considering the firm's years of operation, about 54\% ( $\mathrm{n}=68$ ) have operated for less than five years, while 2\% $(n=2)$ operated between 20 -24 years. The above shows that majority of them firms, $86 \%(n=108)$ started operating less than a decade. Whereas majority $44 \%(n=55)$ relied on the contribution from their partners, a minority of them get their 
source of funding from donor agencies $2 \%(n=3)$. Regarding annual income, about $27 \%(n=34)$ earned above Ghథ 40,001 while 6\% (n=8) earned between Gh\$30,001 to Ghథ 40,000 per annum ${ }^{1}$. Furthermore, $42 \%(n=53)$ of the firms target the low-income group's while $38 \%(n=47)$ target all categories of income earners in the country.

Table 4. Firm Characteristics

\begin{tabular}{|c|c|c|c|c|}
\hline S/N & Variables & Categories & Frequency & Percent \\
\hline 1 & Years of operation & $\begin{array}{c}\text { Less than } 5 \text { years } \\
5 \text { - } 9 \text { years } \\
10 \text { - } 14 \text { years } \\
15-19 \text { years } \\
20 \text { - } 24 \text { years } \\
25 \text { years and above } \\
\text { Total }\end{array}$ & $\begin{array}{c}68 \\
40 \\
6 \\
5 \\
2 \\
4 \\
125\end{array}$ & $\begin{array}{c}54.40 \\
32.00 \\
4.80 \\
4.00 \\
1.60 \\
3.20 \\
\mathbf{1 0 0 . 0 0}\end{array}$ \\
\hline 2 & Source of finance & $\begin{array}{c}\text { Bank loans } \\
\text { Contribution of Partners } \\
\text { Borrowers savings } \\
\text { Share capital } \\
\text { Donor agencies/gov't } \\
\text { Total } \\
\end{array}$ & $\begin{array}{c}26 \\
55 \\
24 \\
17 \\
3 \\
\mathbf{1 2 5} \\
\end{array}$ & $\begin{array}{c}20.80 \\
44.00 \\
19.20 \\
13.60 \\
2.40 \\
\mathbf{1 0 0 . 0 0} \\
\end{array}$ \\
\hline 3 & Firms' annual income* & 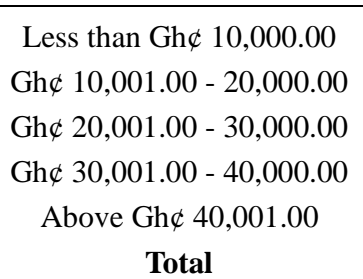 & $\begin{array}{c}26 \\
26 \\
31 \\
8 \\
34 \\
\mathbf{1 2 5}\end{array}$ & \begin{tabular}{c|}
20.80 \\
20.80 \\
24.80 \\
6.40 \\
27.20 \\
$\mathbf{1 0 0 . 0 0}$
\end{tabular} \\
\hline 4 & Target income groups & $\begin{array}{c}\text { Low-income groups } \\
\text { Middle-income groups } \\
\text { Upper-income groups } \\
\text { All } \\
\text { Total } \\
\end{array}$ & $\begin{array}{c}53 \\
22 \\
3 \\
47 \\
125\end{array}$ & $\begin{array}{c}42.40 \\
17.60 \\
2.40 \\
37.60 \\
\mathbf{1 0 0 . 0} \\
\end{array}$ \\
\hline
\end{tabular}

\subsection{The De/Motivation Variables in Housing Microfinance Delivery}

The full list of the de/motivation variables used for the paper is presented in Table 5, and their effects are discussed in Section 4.0 below. The first set of variables is the demotivation variables. They were evaluated, and it emerged that seven out of thirteen variables were considered relevant and they can deter MFIs from entering the low-income housing market. Respondents were impartial on six of these variables. However, their position could as well be interpreted as being

\footnotetext{
${ }^{1}$ As at August 24, 2016 (the time of writing), Gh\$ $1=€ 0,2250=£ 0,1912=\$ 0,2533$.
} 
agreed upon looking at the mean values recorded for those variables which are all above 3.0. The seven most important demotivation variables in order of importance were capital lock-up in HMF delivery (4.85), high-interest rates in the country (4.19), high cost and price of land (4.16), ineffective collateral registry (4.14), high cost and price of building materials (4.12), lack of sufficient collaterals from individual low-income groups (4.10) and the different interest rate required on HMF loans (4.06).

The second twelve set of motivation variables likely to attract MFIs into the low-income housing market were also evaluated using the mean scores as relatively important. The results show that respondents agreed on seven variables being significant motivation variables. The least average score among them was 3.95. These variables in order of importance are MFIs firms desire for expansion (4.44), the potential size of the low-income housing market (4.31), potential market for MFIs growth (4.21), availability of local resources (4.15), the unique features and products of the housing market (4.14), market opportunity for leveraging resources (4.10), and individual low-income groups preference for homeownership over renting (4.02). Respondents were impartial concerning MFIs appetite for profit and high demand for low-income housing. Furthermore, respondents could not agree on issues such as flexibility of entry, the flexibility of risks and knowledge sharing and good policy towards homeownership as motivation variables. These results and their effects are discussed in section 4.0.

Table 5. The De/Motivation Measurement Variables in HMF delivery in the low-income housing market

\begin{tabular}{|l|l|l|l|l|l|l|l|c|c|}
\hline \multicolumn{1}{|c|}{ Coding Measurement Variables } & Nr & Mean & SD & SKN & Rank & Remarks \\
\hline \multicolumn{2}{|c|}{ Demotivations } & 125 & 4.45 & 0.80 & -1.76 & $1^{\text {st }}$ & Agreed \\
\hline Demo3 & Capitals lock-up & 125 & 4.19 & 0.84 & -1.21 & $2^{\text {nd }}$ & Agreed \\
\hline Demo9 & High interest rates & 125 & 4.16 & 0.87 & -1.20 & $3^{\text {rd }}$ & Agreed \\
\hline Demo4 & High cost and price of land & 125 & 4.14 & 1.03 & -1.12 & $4^{\text {th }}$ & Agreed \\
\hline Demo8 & Ineffective collateral registry & 125 & 4.12 & 0.89 & -1.34 & $5^{\text {th }}$ & Agreed \\
\hline Demo6 & High cost and prices of building materials & 125 & 4.10 & 0.93 & -1.30 & $6^{\text {th }}$ & Agreed \\
\hline Demo7 & Lack of sufficient collaterals & 125 & 4.06 & 1.16 & -1.12 & $7^{\text {th }}$ & Agreed \\
\hline Demo10 & Unequal interest charges & 125 & 3.89 & 1.01 & -0.63 & $8^{\text {th }}$ & Neutral \\
\hline Demo12 & Lack of funding & 125 & 3.85 & 1.07 & -0.57 & $9^{\text {th }}$ & Neutral \\
\hline Demo5 & Lack of security and tenure & 125 & 3.70 & 0.93 & -0.24 & $10^{\text {th }}$ & Neutral \\
\hline Demo13 & Low income levels of low income group & 125 & 3.67 & 1.13 & -0.67 & $11^{\text {th }}$ & Neutral \\
\hline Demo2 & HMF delivery is risky & 125 & 3.57 & 1.19 & -0.55 & $12^{\text {th }}$ & Neutral \\
\hline Demo11 & Higher interest rate on HMF & 125 & 3.47 & 1.18 & -0.16 & $13^{\text {th }}$ & Neutral \\
\hline Demo1 & High fold-up rates among MFIs & & & &
\end{tabular}




\begin{tabular}{|l|l|c|c|c|c|c|c|}
\hline \multicolumn{9}{|c|}{ Motivations } & 125 & 4.44 & 0.76 & -1.62 & $1^{\text {st }}$ & Agreed \\
\hline Moti7 & Firms desire for expansion & 125 & 4.31 & 0.88 & -1.59 & $2^{\text {nd }}$ & Agreed \\
\hline Moti1 & $\begin{array}{l}\text { Potential size of the low-income housing } \\
\text { market }\end{array}$ & 125 & 4.21 & 0.86 & -1.28 & $3^{\text {rd }}$ & Agreed \\
\hline Moti8 & Potential market for MFIs growth & 125 & 4.15 & 0.74 & -1.22 & $4^{\text {th }}$ & Agreed \\
\hline Moti5 & Availability of local resources & 125 & 4.14 & 0.78 & -1.09 & $5^{\text {th }}$ & Agreed \\
\hline Moti6 & Unique features and products of the market & 125 & 4.10 & 1.03 & -1.19 & $6^{\text {th }}$ & Agreed \\
\hline Moti9 & Market opportunity for leveraging resources & 125 & 4.02 & 0.99 & -1.19 & $7^{\text {th }}$ & Agreed \\
\hline Moti3 & Preference for homeownership than renting & 125 & 3.98 & 0.99 & -0.98 & $8^{\text {th }}$ & Neutral \\
\hline Moti4 & Appetite to increase firm profit & 125 & 3.95 & 1.08 & -0.98 & $9^{\text {th }}$ & Neutral \\
\hline Moti2 & High demand for low-income housing & 125 & 2.03 & 1.07 & 1.02 & $10^{\text {th }}$ & Disagree \\
\hline Moti11 & Flexibility of entry & 125 & 1.98 & 0.96 & 1.21 & $11^{\text {th }}$ & Disagree \\
\hline Moti12 & Flexibility of risk and knowledge sharing & 125 & 1.73 & 0.89 & 1.47 & $12^{\text {th }}$ & Disagree \\
\hline Moti10 & Good policy towards homeownership & & & & \\
\hline
\end{tabular}

\subsection{Correlation Analysis of the De/Motivation Variables in Housing Microfinance Delivery}

Further analysis was carried out to establish the possible and potential relationships among the identified variables. The Spearman's Rho correlation was employed due to its less sensitivity to skewed data and outliers (Field 2009). Under the demotivation variables, the results show that there is a positive relationship between high cost and price of land and lack of sufficient collaterals [demo 4 and demo 7], $(0.385, \mathrm{p}<0.01, \mathrm{n}=125)$. There is also a positive correlation between lack of security and tenure and high cost and prices of land [demo 5 and demo 4], (0.427, $\mathrm{p}<0.01, \mathrm{n}=125)$. High cost and prices of building materials also correlates positively with lack of sufficient collateral [demo 6 and demo 7], $(0.358, \mathrm{p}<0.01, \mathrm{n}=125)$, high cost and price of land [demo 6 and demo 4] $(0.320, \mathrm{p}<0.01, \mathrm{n}=125)$ and lack of security and tenure [demo 6 and demo 5], $(0.250, \mathrm{p}<0.01, \mathrm{n}=125)$. Lack of funding for MFIs also correlates positively with lack of security and tenure [demo 12 and demo 5], $(0.225, \mathrm{p}<0.01, \mathrm{n}=125)$ and high cost and prices of building materials [demo 12 and demo 6], $(0.316, \mathrm{p}<0.01, \mathrm{n}=125)$. Moreover, low income also correlates positively with lack of sufficient collateral [demo 13 and demo 7], (0.193, $\mathrm{p}<0.05, \mathrm{n}=125)$, lack of security and tenure [demo 13 and demo 5], (0.274, $\mathrm{p}$ $<0.01, \mathrm{n}=125)$, high cost and prices of building materials [demo 13 and demo 6], $(0.232, \mathrm{p}<$ $0.01, \mathrm{n}=125)$ and lack of funding [demo 13 and demo 12], $(0.294, \mathrm{p}<0.01, \mathrm{n}=125)$. The results show that all the demotivation variables have a positive relationship with one or two variables. The strongest positive relationships among them are between high fold-up rates among MFIs and the delivery of HMF being a very risky venture in the low-income housing market 
[demo 1and demo 2], $(0.510, \mathrm{p}<0.01, \mathrm{n}=125)$. The rest of the correlation metrics are shown in Table 6.

The results in Table 7 also show that there is a positive relationship between high demand for low-income housing and the potential of the low-income housing market [Moti 2 and Moti 1], (0.522, $\mathrm{p}<0.01, \mathrm{n}=125)$. There is also a positive correlation between individual low-income groups preference for homeownership and the potential size of the low-income housing market [Moti 3 and Moti 1], (0.372, $\mathrm{p}<0.01, \mathrm{n}=125)$ and high demand for low-income housing [Moti 3 and Moti 2], (0.526, $\mathrm{p}<0.01, \mathrm{n}=125)$. Moreover, a positive relation exists between MFIs appetite for profit and the potential of the low-income housing market [Moti 4 and Moti 1], (0.238, $\mathrm{p}<0.01, \mathrm{n}=125)$ and high demand for low-income housing [Moti 4 and Moti 2], (0.229, $\mathrm{p}<0.01, \mathrm{n}=125$ ). There is also a positive relationship between most of the motivation variables. Two variables-low-income housing market and the opportunity for leveraging resource correlates positively with all other variables. The correlations are shown in Table 7. 
Table 6. The Correlation Analysis of the Demotivation Variables

\begin{tabular}{|c|c|c|c|c|c|c|c|c|c|c|c|c|c|c|}
\hline \multicolumn{15}{|c|}{ Correlations } \\
\hline & & & Moti 1 & Moti 2 & Moti 3 & Moti 4 & Moti 5 & Moti 6 & Moti 7 & Moti 8 & Moti 9 & Moti 10 & Moti 11 & Moti 12 \\
\hline \multirow[t]{23}{*}{ Spearman's rho } & Moti 1 & $\begin{array}{l}\text { Correlation Coefficient } \\
\text { Sig. (2-tailed) }\end{array}$ & 1.000 & & & & & & & & & & & \\
\hline & Moti 2 & Correlation Coefficient & $.522^{* *}$ & 1.000 & & & & & & & & & & \\
\hline & & Sig. (2-tailed) & .000 & & & & & & & & & & & \\
\hline & Moti 3 & Correlation Coefficient & $.372^{* *}$ & $.526^{* *}$ & 1.000 & & & & & & & & & \\
\hline & & Sig. (2-tailed) & .000 & .000 & & & & & & & & & & \\
\hline & Moti 4 & Correlation Coefficient & $.238^{* *}$ & $.229^{*}$ & .164 & 1.000 & & & & & & & & \\
\hline & & Sig. (2-tailed) & .008 & .010 & .068 & & & & & & & & & \\
\hline & Moti 5 & Correlation Coefficient & $.234^{* *}$ & $.269^{* *}$ & .125 & $.569^{* *}$ & 1.000 & & & & & & & \\
\hline & & Sig. (2-tailed) & .009 & .002 & 165 & .000 & & & & & & & & \\
\hline & Moti 6 & Correlation Coefficient & $.240^{* *}$ & $.217^{*}$ & .050 & $.461^{* *}$ & $.591^{* *}$ & 1.000 & & & & & & \\
\hline & & Sig. (2-tailed) & .007 & .015 & .579 & .000 & .000 & & & & & & & \\
\hline & Moti 7 & Correlation Coefficient & 172 & .094 & $.201^{*}$ & 148 & $.185^{*}$ & $.321^{* *}$ & 1.000 & & & & & \\
\hline & & Sig. (2-tailed) & .055 & 296 & .025 & 099 & .039 & .000 & & & & & & \\
\hline & Moti 8 & Correlation Coefficient & .099 & $.187^{*}$ & $.264^{* *}$ & 152 & $.242^{* *}$ & $.272^{* *}$ & $.650^{* *}$ & 1.000 & & & & \\
\hline & & Sig. (2-tailed) & 273 & .037 & .003 & .090 & .006 & .002 & .000 & & & & & \\
\hline & Moti 9 & Correlation Coefficient & $.283^{* *}$ & $.479^{* *}$ & $.266^{* *}$ & $.279^{* *}$ & $.356^{* *}$ & $.416^{* *}$ & $.184^{*}$ & $.391^{* *}$ & 1.000 & & & \\
\hline & & Sig. (2-tailed) & .001 & .000 & .003 & .002 & .000 & .000 & .040 & .000 & & & & \\
\hline & Moti 10 & Correlation Coefficient & -.019 & .097 & .093 & -.025 & .007 & -.027 & .089 & .077 & .055 & 1.000 & & \\
\hline & & Sig. (2-tailed) & .834 & 280 & .302 & .782 & .938 & .766 & .323 & .393 & .541 & & & \\
\hline & Moti 11 & Correlation Coefficient & .058 & 115 & .032 & 059 & .095 & .099 & .047 & .005 & .122 & $.508^{* *}$ & 1.000 & \\
\hline & & Sig. (2-tailed) & .519 & .203 & .726 & .515 & 290 & .273 & .600 & .956 & .175 & .000 & & \\
\hline & Moti 12 & Correlation Coefficient & .106 & .145 & .123 & .051 & .043 & .061 & -.002 & -.007 & .078 & $.304^{* *}$ & $.528^{* *}$ & 1.000 \\
\hline & & Sig. (2-tailed) & .238 & .108 & .172 & .569 & .633 & .499 & .986 & .936 & .389 & .001 & .000 & \\
\hline
\end{tabular}

*. Correlation is significant at the 0.01 level (2-tailed) 
Table 7. The Correlation Analysis of the Motivation Variables

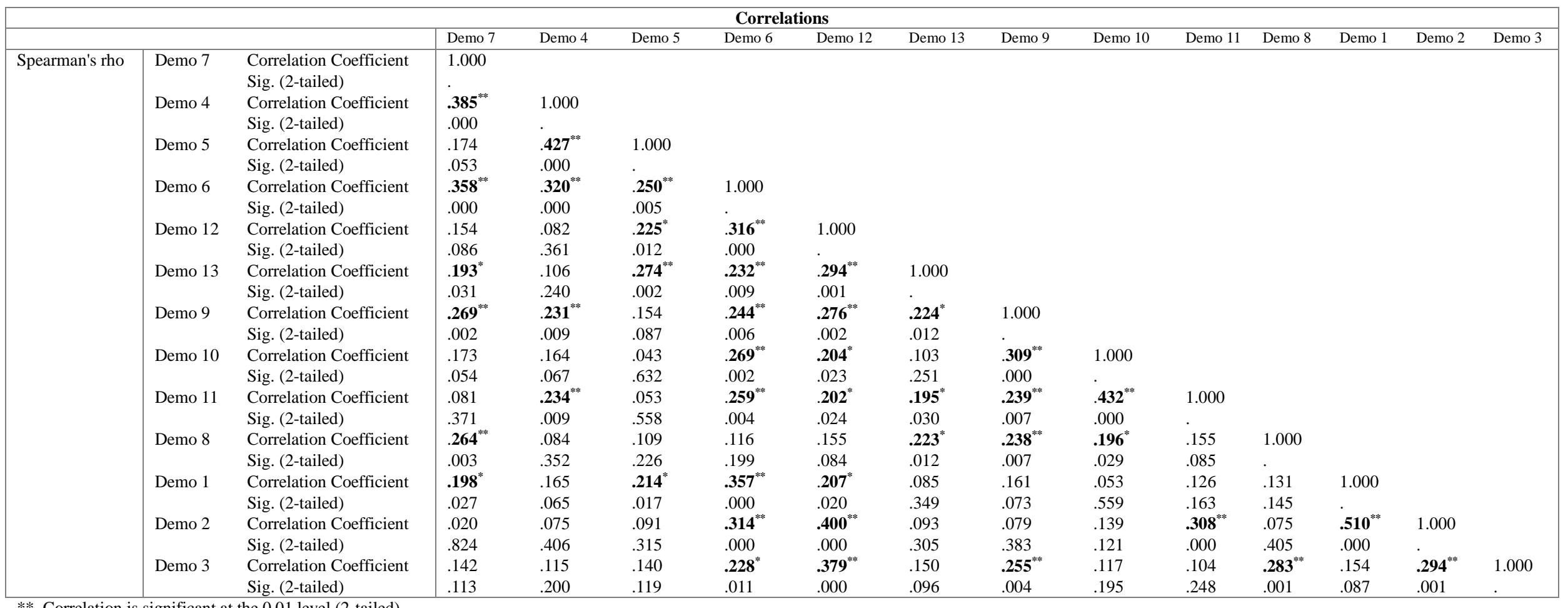

* Correlation is significant at the 0.01 level (2-tailed)

*. Correlation is significant at the 0.05 level (2-tailed). 


\subsection{Discussion of the Findings and Implications}

\subsection{The effect of the demotivation variables on housing microfinance delivery}

There is a perceived high risk of default among individual low-income groups to traditional financial institutions. However, the situation of high defaults according to (Quaye et al. 2014) seems different with the microfinance industry. Thus, other MFIs have been able to succeed in the provision of financial assistance which aided individual low-income groups in Ghana to achieve financial independence progressively. This can be possible through their strong competency in the utilisation of scarce resources to effectively serve the informal sector. However, most MFIs are not willing to engage in the low-income housing market especially with HMF products due to many reasons. These reasons include lack of inadequate capital to finance low-income housing activities. This is because low-income housing activities require a significant capital outlay that is sometimes also locked-up. Coupled with the prevailing high interest rates on borrowing in Ghana, it is very difficult for most MFIs to consider new markets such as the low-income housing market even though such markets are perceived to be profitable.

The results of the survey show that majority of MFIs operates in the Greater Accra region than in the Ashanti region with close to $18 \%$ of all the respondents having a sound knowledge about HMF in the country. The results demonstrate that there is little awareness among MFIs about the potential of both HMF as a product and that of the low-income housing market. Research and education are, therefore, fundamental to uncover the potential of both sub-sectors to MFIs and individual low-income groups in the country. Many MFIs offer micro savings than other products which go to buttress the point that most MFIs are operated by private concerns and individuals who aim at maximising profits out of the various low-income group's savings. MFIs by concentrating on micro savings escaped and passed on the risks involved in giving out microloans to individual low-income groups to meet their housing needs. Individual low-income groups often suffer the risks of losing their money in the event of bankruptcy of these companies.

It is, therefore, safer and secure in taking savings than giving out credits when MFIs seems not to have any sustainable and secure source of funding. Only about 3\% of the respondent organisations were involved in some form of HMF activities. They were probably compelled to do so due to some of their clients' diverting enterprise loans into housing improvement as always 
being the case. It is also evidenced that MFIs which offers HMF do so due to their source of funding and partner's interest.

Moreover, the general market situation in Ghana looks scary for most MFIs. The country macro economic environment affects the effective implementation of HMF programmes. As stated above, due to the market conditions and risk of non-payments, many MFIs priced their HMF portfolios to cater for such eventualities. This ultimately makes them very expensive and inaccessible to individual low-income groups. Moreover, the income levels of many individual low-income groups are low in the country in contrast to the cost of building a house. This is often because of high cost of materials and land, which consequently leads to high cost of construction that becomes unaffordable for individual low-income groups. Low-income is, therefore, a function of both individual low-income groups and MFIs motivation which also affect the affordability of HMF products and their delivery in the country. Cultural issues also demotivate MFIs from adopting HMF for the housing market due to a perception in Ghana concerning gender and home ownership. Homeownership is skewed towards men. However, many MFIs target mostly women, and this serves as a demotivation. Regulatory framework and building codes are also potential demotivators in the delivery of HMF in the country. Other important issues such as high cost and delay of licensing or building permit process (permits for the use of the space, location permits, and land certification) are equally demotivating to MFIs in the country. These and unreliable title documentations intensify the risk of HMF lending, which explains why some MFIs in Ghana often shy away from lending to individual low-income groups to meet their needs or do so at a very high premium.

\subsection{The effect of the motivation variables on housing microfinance delivery}

The perceived motivation that would make most MFIs to be engaged in the low-income housing market would mainly be about profitability in both microfinance and low-income housing sectors. With profit-maximizing options as key, producing and selling more of housing products or units, reducing the cost of production through local raw materials and labour cost per housing unit would have normally been given priority by MFIs. However, this has not been the case as most MFIs motivations could be linked to some internal and external variables and processes. These variables and processes stimulate their desires and drive them to be continually interested and committed to pursuing certain goals or course of action. Therefore, they would usually 
employ persistent efforts in attaining these firm goal(s). MFIs internal motivation variables which can be considered as influential are the firm's desire for expansion, the appetite for profit and growth. Others are the firm structure, business interest, strategy and resources. The influential external variables include the potential size of the low-income housing market, the potential market for MFIs growth; availability of local resources to support HMF delivery; unique features and products of the market and the market opportunity for leveraging resources in both sectors. These variables collectively will either pull or attract MFIs into the low-income housing markets depending on their severities and other conditions. Interestingly, many MFIs have also acknowledged that the low-income housing market is large enough to accommodate both traditional, universal banks and MFIs. Such accession serves as motivation to other MFIs which can make a significant stride in the market. In many cases, they could be motivated by variables which include their corporate mission of meeting the socio-economic needs of the urban poor through the provision of housing, the potential of the housing market and MFIs willingness to enhance their corporate image and create employment for the urban and rural poor.

In a much broader perspective, the intrinsic motivation by MFIs to provide a stable and safe livelihood through the housing as well as offering financial security to individual low-income groups would constitute one of their safety needs. The safety needs of individual low-income groups in the delivery of HMF by MFIs would help generate a feeling of acceptance, sense of belongingness within the communities where they operate. The use of HMF in delivering lowincome housing would also reinforce team dynamics among individual low-income groups. Additionally, meeting the social needs of individual low-income groups through the provision of housing would help MFIs recognise their achievements in the housing product delivered and assign priorities to other valuable products. This would also provide status and rewards that would make MFIs customers feel valued and appreciated. Under esteem motivation perspective, the delivery of HMF would offer a challenging and meaningful work assignment which would enable innovation, creativity, and progress by the long-term goals of MFIs. Furthermore, the participation of individual low-income groups in their housing decision making would offer job flexibility and autonomy among them and thereby enhance their self-actualization. The driving force of motivation in MFIs would help puts human and financial resources to action which would intend builds a friendly relationship between MFIs and individual low-income groups. It 
would also possibly foster a mutual partnership between MFIs, individual low-income groups, the community and the state. In the case of individual low-income groups, motivation would help them achieve their personal or individual goals of building or improving their houses which will lead to personal self-esteem and satisfaction. It would also enhance skills and self-development of individual low-income groups since they would build through the incremental process by working with or in groups of dynamic teams. An understanding of these sectors activities in the country is still low among practitioners and the research community. The implications of the above findings are that the interactions between these two important submarkets in Ghana economy need a careful and systematic study.

\subsection{Conclusion}

Over the years existing literature on housing finance in emerging markets context has very little empirical work around HMF for low-income housing delivery. This paper provides an empirical framework for understanding some dimensions of HMF delivery relevant to MFIs, individual low-income groups, policy makers and investors. One major contribution of this paper is that it has evaluated the variables that are likely to deter and attract new MFIs into the low-income housing market by the adoption of HMF. It has therefore contributed to the extant literature on low income housing finance in developing countries. The study implies that within the lowincome housing finance domain, there are both de/motivation variables that could help explain the demand and supply phenomenon of HMF. The twenty-five variables could be used by management of MFIs as critical variables in evaluating their decisions in lending to individual low-income groups.

The paper concludes that since HMF is quite new to the Ghanaian low-income housing market, the study views it as an innovative financing strategy. However, the demotivators outweighed the motivators which are not making the market attractive to many MFIs. Furthermore, HMF can provide the housing needs of a large segment of individual low-income groups if MFIs operate within a well-conceived competitive environment where there is the possibility of charging consumers the real cost and making a profit out of HMF. Stakeholders within the sector from both demand and supply sides must come together to form a united front through the efforts of Ghana Microfinance Institutions Network (GhaMFIN) to address some of the bottlenecks 
identified. Proper engagement with state institutions on critical issues concerning land administration, management and provision of infrastructure remains vital in attracting many MFIs into the low-income housing market.

It is however cautioned that the results of the present paper should be interpreted within the context of Sub-Sahara Africa, especially Ghanaian low-income housing market, and similar studies should be done in similar contexts in different countries to compare the results before generalisations could be made. Finally, the variables of each dimension of motivation identified for HMF delivery are not exhaustive. Different country-specific contexts may require modifications to the variables; the expansion of these variables could be grouped under each dimension as well as the inclusion of additional variables as knowledge keeps evolving and existing policies and practices keep changing. Therefore, future research should explore other critical factors in different developing countries for a better understanding of HMF delivery relevant to the low-income housing market. Further research is also required, concerning the risk, challenges and barriers to the adoption and delivery of HMF to individual low-income groups to meet their housing needs. There is also the need to study the low-income housing market dynamics in the country to understand the motivation behind individual low-income group's decision to use HMF and vice versa.

\section{References}

Afrane, S. K., Owusu-Manu, D., Donkor-Hyiaman, K. A. and Bondinuba, F. K., (2014) 'Towards Innovative Housing Financing in Ghana: An Evidence-Based from South Africa's Pension Housing Financing System’, Public Policy and Administration Research, 4(4).

Ahmed, F., Brown, B. and Williams, S. P., (2013) 'Is It Time to Regulate Microfinance?', Progress in Development Studies, 13(3), 209-220.

Akinola, S. R., (2007) 'Coping with Infrastructural Deprivation through Collective Action among Rural People in Nigeria’, Nordic Journal of African Studies, 16(1) 30-46.

Arku, G., Luginaah, I., and Mkandawire, P., (2012) 'You Either Pay More Advance Rent or You Move Out”: Landlords/Ladies’and Tenants’ Dilemmas in the Low-income Housing Market in Accra, Ghana’ Urban Studies, 49(14) 3177- 3193. 
Awuvafoge, S. A., (2013) Affordable Housing in Urban Areas in Ghana: Issues and Recommendations, A Research Paper. Ball State University, Indiana.

Babbie, E., (2007) The Practice of Social Research, 11th Ed. Belmont, CA: Wadsworth.

Basu, A., Blavy, R. and Yulek, M., (2004) Microfinance in Africa: Experience and Lessons from Selected African Countries, IMF Working Paper WP/04/174, World Bank, Washington DC.

Boamah, N.A., (2010) Housing affordability in Ghana: a focus on Kumasi and Tamale. Ethiopian Journal of Environmental Studies and Management, 3(3).

BOG, (2007) The Housing Industry in Ghana: Prospects and Challenges, Bank of Ghana Policy Briefing Paper. Bank of Ghana: Accra.

Bondinuba F. K., (2016) 'The Role of Microfinance as an Innovative Strategy for Low-income Housing Delivery in Developing Countries' (Doctoral Dissertation, Heriot-Watt University)

Bondinuba F. K., Karley N. K., Biitir S. B. and Adjei-Twum A., (2016) 'Assessing the Role of Housing Microfinance in the Low-income Housing Market in Ghana', Journal of Poverty, Investment and Development 28, 44-54.

Bondinuba, F. K., (2015) July. Exploring the Motivational Factors for Microfinance Institutions Entry and Non-Entry into the Housing Market in Ghana. In Proceeding of New Researchers Colloquium ENHR 2015Annual Conference ENHR 2015 Housing and Cities in a time of Change: are we focusing on People? (Lisboa, Portugal), 28 June-1July 2015; ENHR.

Bondinuba, F. K., Nimako, S. G. and Karley, N. K., (2013) 'Developing Student Housing Quality Scale in Higher Institutions of Learning: A Factor Analysis Approach', Urban Studies Research, Article ID 383109, 11 pages, 2013. doi:10.1155/2013/383109.

Bondinuba, F. K., Stephens, M. and Colin A. (2014) July. Innovative Financing Strategy for LowIncome Housing Delivery in Developing Countries. In Stephens, M. (Eds.), eBook of Abstracts Proceedings of New Researchers Colloquium ENHR 2014 Conference, Beyond Globalisation: Remaking Housing Policy in a Complex World, (Edinburgh, United Kingdom), 1-4 July 2014; ENHR. 1-10.

Buckley, R. M. and Kalarickal, J., (2005) 'Housing Policy in Developing Countries: Conjectures and Refutations', The World Bank Research Observer, 20(2) 233-257.

CAHF, (2015) 2015 Yearbook, Housing Finance in Africa. Centre for Affordable Housing Finance in Africa. 
Cain, A., (2007) 'Housing Microfinance in Post-Conflict Angola. Overcoming Socioeconomic Exclusion through Land Tenure and Access to Credit', Environment and urbanisation, 19 (2) 361-390.

Calvo, G. A., Leiderman, L. and Reinhart, C. M., (1996) 'Inflows of Capital to Developing Countries in the 1990s', The Journal of Economic Perspectives, 123-139.

Chakrabarti, R., (2004) The Indian Microfinance Experience, 'Integrating the Rural Poor into Markets’ 137.

Coase, R., (1998) 'The New Institutional Economics’ American Economic Review, 72-74.

Daphnis, F. and Ferguson, B., (Eds.) (2004) Housing Microfinance: A Guide to Practice Kumarian Press.

Derban, W. K., Derban, D. K., Ibrahim, G. and Rufasha, K., (2002) Microfinance for Housing for Low/Moderate Income Households in Ghana. In Conference on Housing and Urban Development for Low-Income Groups in Sub-Saharan Africa, Accra. 22-26.

Ferguson, B. and Navarrete, J., (2003) 'New Approaches to Progressive Housing in Latin America: A Key to Habitat $\quad$ Programs and Policy’, Habitat International, 27(2) 309-323.

Ferguson, B. and Smets, P., (2010) 'Finance for Incremental Housing; Current Status and Prospects for Expansion', Habitat International, 34(3) 288-298.

Ghana Statistical Service, (2013) 2010 Population and Housing Census: Summary Report of Final Results. Retrieved from Ghana Statistical Service: http://www.statsghana.gov.gh/docfiles/2010phc/Census2010_Summary_report of_final_results.pdf [Accessed 21 August 2013].

Habitat, U. N., (2006) State of the World's Cities. The Millennium Development Goals and Urban Sustainability.

Jack, M. and Braimah, F., (2004) Feasibility Study for the Application of Community-Led Infrastructure Finance Facility (CLIFF) Operations in Ghana, United Nations Human Settlements Programme.

Karley, N.K., (2008) Ghana Residential Property Delivery Constraints and Affordability Analysis. Housing Finance International, 22(4), 22.

Keeter, S., Miller, C., Kohut, A., Groves, R. and Presser, R., (2000) 'Consequences of Reducing Nonresponse in a National Telephone Survey’ Public Opinion Quarterly 64(125) 48. 
Keivani, R. and Werna, E., (2001) 'Modes of Housing Provision in Developing Countries’, Progress in Planning, 55(2) 65-118.

Klijn, E. and Teisman, G. R., (2002) 'Institutional and Strategic Barriers to Public-PrivatePartnerships: An Analysis ～of Dutch Cases’ Money and Management, 23(3) 137-146.

Klijn, E. H. and Koppenjan, J. F., (2000) 'Public Management and Policy Networks: Foundations of a Network Approach to Governance.' Public Management and International Journal of Research and Theory, 2(2) 135-158.

Kono, H. and Takahashi, K., (2010) 'Microfinance Revolution: Its Effects, Innovations, and Challenges’ The Developing Economies, 48(1) 15-73.

Krieger, J. and Higgins, D. L., (2002) 'Housing and Health: Time Again for Public Health Action' American Journal of Public Health, 92(5) 758-768.

Kumar, A. (2004) 'Partnerships for Urban Infrastructure Development in India' Global Business Review, 5(73) 73- 96.

Kwofie, T. E., Adinyira, E. and Botchway, E., (2011) Historical Overview of Housing Provision in Pre-and Post-Independent (ce) Ghana. In: Laryea, S., Leringer, R. and Hughes, W. (Eds.) Procs West Africa. Built Environment Research (WABER) Conference, 19-21 July 2011, Accra, Ghana, 541-557.

Lerbs, O. W., (2014) 'House Prices, Housing Development Costs, and the Supply of New SingleFamily Housing in German Counties and Cities’ Journal of Property Research, 31(3)183-210.

Littlefield, E., Morduch, J. and Hashemi, S., (2003) 'Is Microfinance an Effective Strategy to Reach the Millennium Development Goals?', Focus Note, 24(2003)1-11.

Madu, E. N. and Umebali, E., (1993) 'Self-help Approaches to Rural Transformation in Nigeria', Community Development Journal, 28(2)141-153.

Malhotra, M., (2003) 'Financing her Home, one Wall at a Time', Environment and Urbanization, 15(2) 217-229.

Merkle, D. and Edelman E., (2002) Nonresponse in Exit Polls: A Comprehensive Analysis in Survey Nonresponse, Ed. Robert M. Groves, Don A. Dillman, John L. Eltinge, and Roderick J. A. Little, New York: Wiley.

Metzel S., (2009) Housing Paradigms and Housing Microfinance [Online] [Available at] http://housingandmicrofinance.blogspot.co.uk. (Accessed 18 February 2014)

Nima, A., (2004) Strategic Assessment of the Affordable Housing Sector in Ghana. 
Nimako, S. G. and Bondinuba, F. K., (2013) 'Relative Importance of Student Accommodation Quality in Higher $\quad$ Education', Current Research Journal of Social Sciences, 5(4) 134-142.

Obeng-Odoom, F., (2013) Governance for Pro-Poor Urban Development: Lessons from Ghana. Routledge.

Pallant, J., (2010) A Step by Step Guide to Data Analysis Using the SPSS Program. SPSS Survival Manual 4th ed. Australia: Allen and Unwin Books.

Panayotou, T., (2002) 'Innovative Financial Mechanisms for Sustainable Sector Financing', Testing New Policy Approaches, 303.

Pedrini, M., Bramanti, V., Minciullo, M. and Ferri, L. M., (2016) 'Rethinking Microfinance for Developed Countries’, Journal of International Development, 28(2) 281-302.

Quaye, I., Abrokwah, E., Sarbah, A. and Osei, J. Y., (2014) 'Bridging the SME Financing Gap in Ghana: The Role of Microfinance Institutions', Open Journal of Business and Management, 2, 339-353 http://dx.doi.org/10.4236/ojbm.2014.24040

Ritchie, (2011) An Introduction to Housing Microfinance: A Workshop Presented by the Housing Microfinance Working Group Tanzania at the Russian Cultural Centre, Dares Salaam $8^{\text {th }}$ June 2011- 2:00 pm -5:00 pm

Sarfoh, K.O., 2010. Lost in the translation-the nexus of multi-layered housing policy gaps: the case of Ghana (Doctoral dissertation, University of St Andrews).

Schumman, R., (2004) Developing Housing Microfinance Products in Central America, Accion's InSight Series, (12).

Sengupta, N., (2013) 'Poor Women's Empowerment: The Discursive Space of Microfinance', Indian Journal of Gender Studies, 20(2) 279-304.

Smets, P., (2006) Small is Beautiful, but Big is often the Practice: Housing Microfinance in Discussion. Habitat International, 30(3) 595-613.

Srnec, K., Neradová, A. and Hes, T., (2013) 'Socio-Economic Profile of Village Bank Member in Suburban Ankara: Microcredit Mannequin and Assumptions on Microfinance Market of Turkey’, International Letters of $\quad$ Social and Humanistic Sciences, (07) 55-75.

Stiglitz, J. E., (1993) The Role of the State in Financial Markets (Vol. 21). Institute of Economics, Academia Sinica.

Tipple, G., Korboe, D., Garrod, G. and Willis, K., (1999) 'Housing Supply in Ghana: A Study of Accra, Kumasiand Berekum', Progress in Planning, 51(4) 255-324. 
UNCHS, (United Nations Centre for Human Settlements) (1996) An Urbanising World: Global Reports on Human Settlement, Oxford University Press, Oxford.

Yankson, P. W. and Gough, K. V., (2014) Urban Low-Income Housing in Ghana. Affordable Housing in the Urban Global South: Seeking Sustainable Solutions, 381.

Yunus, M., (2007) 'Banker to the Poor: Micro-Lending and the Battle Against World Poverty' Public Affairs. 